TELAGA BAHASA

Volume 5

No. 2 Desember 2017

Halaman 213-226

\title{
BUDAYA JAWA DALAM NOVEL MARS \\ KARYA AISHWORO ANG: TINJAUAN ANTROPOLOGI SASTRA
}

(Javanese Culture in Novel Mars by Aisworo Ang: A Literary Anthropology Study)

Dian Nathalia Inda

Balai Bahasa Kalimantan Barat

Jalan Jenderal Ahmad Yani No. 4, Parit Tokaya

Pontianak Selatan, Kalimantan Barat, 78113

Pos-el: diannathalia2812@gmail.com

\begin{abstract}
Abstrak
Penelitian ini bertujuan memaparkan keberagaman budaya Jawa yang terkandung dalam novel Mars dengan menggunakan teori antropologi sastra. Sumber data dalam penelitian ini berasal dari novel Mars. Pengumpulan data menggunakan metode studi pustaka, sedangkan analisis data menggunakan metode deskriptif analisis Hasil analisis menunjukkan keberagaman budaya Jawa yang ada di novel Mars berupa tradisi dan adat kebiasaan, kesenian, bangunan adat, agama dan kepercayaan tradisional. Kebudayaan Jawa tersebut ada yang telah terkikis, tetapi ada juga yang masih bertahan dan dilaksanakan rutin setiap tahun.
\end{abstract}

Kata Kunci: Mars, budaya Jawa, dan antropologi sastra

\section{Abstract}

This research aimed to describe the variety of Javanese culture that contained in novel Mars by using the theory of literary anthropology. The source of data was novel Mars. The purpose of this paper is to describe the Javanese cultures on novel Mars. Data were analyzed using descriptivequalitative method with literature review technique. The results of the analysis showed the diversity of Javanese culture that exists in the novel of Mars in the form of traditions and customs, arts, traditional buildings, religions, and traditional beliefs. Javanese culture has been eroded, but some are still routinely held every year.

Keywords: Mars, Javanese culture, and literary anthropology 


\section{PENDAHULUAN}

Indonesia adalah negara yang memiliki keanekaragaman budaya artinya kebudayaan yang ada pada suatu etnik di satu daerah memiliki keunikan dan kekhasan tersendiri, dari budayanya makanya identitas suatu daerah dapat diketahui. Arus globalisasi dan modernisasi yang semakin gencar membuat masyarakat, khususnya generasi muda mulai melupakan bahkan tidak tahu kebudayaan yang selama ini terdapat di dalam masyarakatnya. Ketidakpedulian dan ketidaktahuan ini perlahan-lahan akan mengerus kebudayaan yang ada sehingga akhirnya hilang tiada bekas sehingga perlu adanya upaya untuk melestarikan dan memasyarakatkan kebudayaan daerah yang ada. Salah satu upaya pelestarian budaya dapat dilakukan melalui suatu karya sastra, bahasa sebagai media penghantar karya sastra menjembatani hubungan sastra dan kebudayaan sehingga dapat dipahami secara utuh.Salah satu karya sastra yang berisi muatan budaya daerah adalah novel Mars.

Novel Mars adalah novel yang ditulis oleh Aisworo Ang. Novel Mars menceritakan kehidupan masyarakat dusun Manggarsari, Gunung Kidul. Gunung Kidul merupakan sebuah kabupaten yang terletak di Daerah Istimewa Yogyakarta. Keadaan alam Gunung Kidul yang berbukit dan bergunung kapur menyebabkan daerah ini tandus dan gersang. Namun, dibalik daerah yang tandus ini tersimpan berbagai budaya yang unik.Aishworo Ang sebagai seorang pengarang yang berasal dari Gunung Kidul mampu menuangkan fenomena budaya yang unik dan khas di daerahnya ke dalam novel Mars secara apik dan indah. Sayang sekali bila kebudayaan yang terdapat dalam novel ini dibiarkan begitu saja tanpa diketahui masyarakat luas, khususnya masyarakat Jawa.

Berdasarkan latar belakang tersebut, tulisan ini akan menggambarkan kebudayaan yang terkandung dalam novel Mars, makna dan dampaknya terhadap kondisi masyarakat saat ini. Adapun permasalahan dalam tulisan ini adalah kebudayaan apa saja yang dimiliki oleh etnik Jawa di daerah Gunung Kidul yang terdapat dalam novel Mars. Tujuan penelitian ini adalah mengungkapkan kebudayaan Jawa yang terdapat di novel Mars. Penelitian ini juga diharapkan dapat menjadi bahan rujukan yang memperkaya kekayaan budaya bangsa terutama tradisi dan budaya suatu etnik khususnya etnik Jawa.

Berkenaan dengan tulisan ini, penulis telah melakukan kajian pustaka yang pernah dilakukan terhadap novel Mars.Sepengetahuan penulis, tulisan yang berkenaan dengan novel Mars merupakan hasil kajian David Wisnu Aji pada tahun 
2014 berjudul "Aspek kepribadian Tokoh Utama Dalam Novel Mars Karya Aishworo Ang: Kajian Psikologi Sastra Dan Implementasinya Sebagai Bahan Ajar Di SMA".Tulisan tersebut menelaah aspek kejiwaaan tokoh utama, yaitu Tupon yang rela bekerja keras untuk menyekolahkan anaknya, Palupi melalui pendekatan psikologi sastra tetapi belum membahas mengenai budaya yang terkandung di dalam novel Mars karenanya, penelitian ini akan merepresentasikan keberadaan budaya Jawa yang ada di dalam novel tersebut.

\section{TEORI}

Sastra yang memiliki rekaman budaya suatu daerah di dalamnya layak dipahami melalui antropologi sastra. Antropologi sastra adalah kajian yang menekankan pada warisan budaya masa lalu yang nampak pada karya sastra sehingga dapat dikaji lewat paparan etnografi yang ada pada karya sastra tersebut sebagai data. Hal ini sesuai pernyataan Endraswara (2015: 1) yang menyatakan bahwa bahan penelitian antropologi sastra adalah sikap dan perilaku manusia lewat fakta-fakta sastra dan budaya. Antropologi sastra berupaya meneliti sikap dan perilaku yang muncul sebagai budaya dalam karya sastra. Ratna juga mendeskripsikan antropologi sastra sebagai analisis dan pemahaman terhadap karya sastra dalam kaitannya dengan kebudayaan. Baginya, karya sastra merupakan sebuah sumber yang relevan dalam rangka menjelaskan kondisi masyarakat tertentu.

Representasi merupakan gambaran apa saja yang ada dalam karya sastra. Cavallaro dalam Endraswara (2015: 28) menyatakan bahwa representasi sejajar dengan citra. Menurutnya, penelitian antropologi sastra dapat mengungkap pencitraan budaya dalam sastra. Representasi yang diungkap antara lain (a) penampilan dramatis tokoh; (b) fakta-fakta setting tradisi; (c)fenomena alam, sosial, interaksi multikultural, dan sebagainya. Lebih lanjut, Ratna (2011: 73-74) juga memaparkan adanya keterkaitan antropologi sastra dengan tradisi, adat istiadat, mitos, dan peristiwaperistiwa kebudayaan pada peristiwaperistiwa masa lampau.Kebudayaan adalah keseluruhan system gagasan, tindakan, dan hasil karya manusia dalam rangka kehidupan masyarakat yang dijadikan milik diri manusia dengan belajar (Koentjaraningrat, 1986:180). Ratna (2010: 26) juga menyebutkan apabila secara definitif. kebudayaan merupakan keseluruhan kelakuan dan hasil kelakuan manusia, maka masyarakat adalah jaringan manusia yang mewadahi kebudayaan tersebut. 


\section{METODE}

Metode yang digunakan dalam penelitian ini adalah metode deskriptif kualitatif. Metode ini dilakukan dengan cara mendeskripsikan/menggambarkan budaya yang terdapat dalam novel Mars. Jenis penelitian yang digunakan adalah kajian kepustakaan. Dengan demikian, objek penelitian, referensi, dan rujukan-rujukan lain penulis peroleh dari sumber-sumber tertulis. Adapun objek yang diteliti adalah novel yang berjudul Marskarya Aishworo Ang edisi pertama diterbitkan oleh Penerbit Safirah pada tahun 2011 yang berjumlah 388 halaman. Untuk selanjutnya, novel tersebut ditempatkan sebagai sumber data dalam upaya merepresentasikan budaya Jawa, terutama budaya masyarakat Jawa di Gunung Kidul yang terdapat dalam novel tersebut.

Pengumpulan data yang digunakan dalam penelitian ini adalah studi kepustakaan dengan teknik catat, yaitu mencatat hal atau temuan data yang dijadikan model analisis data. Pengolahan data dilakukan dengan langkah (1) menelaah data, yaitu membaca novel Mars; (2) mencatat data yang berhubungan dengan kebudayaan Jawa yang terdapat di dalam novel Mars; (3) menganalisis dan mendeskripsikan ragam budaya Jawa yang terdapat dalam novel tersebut.

\section{PEMBAHASAN}

\section{Ringkasan Cerita dalam Novel Mars}

Novel ini mengisahkan tentang perjuangan seorang ibu dalam menyekolahkan gadis kecilnya yang bernama Palupi. Mereka tinggal di Dusun Manggarsari, Gunung Kidul dalam keadaan yang serba kekurangan. Keterbatasan ekonomi yang mereka miliki tidak mematahkan semangat Palupi untuk terus bersekolah tinggi meraih cita-citanya. Nilainilai budaya yang ada di masyarakat yang dianut dipadukan dengan nilai religius dan intelektualitas menjadikan Palupi memiliki karakter bersahaja. Akhirnya Palupi dapat meraih predikat sebagai seorang lulusan terbaik pascasarjana Oxford University London serta memenangkan kompetisi riset ilmiah tingkat internasional bidang astronomi.

Berikut ini keberagaman budaya Jawa yang terkandung dalam novel Mars.

\section{Tradisi dan Adat Kebiasaan}

Salah satu wujud kebudayaan dapat berupa upacara tradisional. Di dalam sendi kehidupan masyarakat Jawa selalu terdapat upacara adat, selamatan atau tradisi tertentu yang dilakukan untuk memperingati suatu peristiwa tertentu. Tradisi dan adat kebiasaan masyarakat jawa yang hingga saat ini masih 
bertahan adalah tradisi munggah molo, pada umumnya dan Kabupaten Gunung rasulan, gumbregan, dan gaduhan.

Tradisi Munggah Molo

Masyarakat Jawa yang ada di daerah Gunung Kidul mempunyai suatu tradisi yang berkaitan dengan rumah. Pada saat Kidul khususnya, rumah dianggap sebagai perwujudan miniatur alam semesta yang memiliki kekuatan supranatural sehingga rumah perlu dihormati dan disakralkan. Membangun rumah adalah ibarat memperbaiki rumah atau membangun rumah membangun alam raya dimana penghuninya akan hidup dan menjalankan misi hidupnya. ada sebuah tradisi yang masih Oleh karena itu, masyarakat Jawa melakukan dipertahankan oleh masyarakat Gunung Kidul, yaitu tradisi munggah molo. Berikut ini kutipan yang menggambarkan tradisi munggah molo.

"Saya minta tolong nanti pas acara munggah molo, panjenengan yang memimpin doa, ya, Mas."

Ali terkejut mendengarnya. Selama hampir dua setengah tahun tinggal di Dusun Manggarsari, belum pernah Ali memimpin ritual tradisional, seperti halnya munggah molo. Tradisi yang dijalankan oleh sebagian masyarakat Jawa ketika hendak memperbaiki atau mengganti bagian-bagian rumah (Ang, 2015: 64).

Kutipan tersebut menunjukkan tokoh Ali yang didatangi Kang Trimo. Kang Trimo ingin merenovasi rumahnya sehingga ia meminta tolong pada Ali untuk memimpin ritual munggah molo, ritual tradisional yang dilakukan untuk memperbaiki atau membangun rumah. Bagi masyarakat Jawa tradisi munggah molo sebagai wujud penghargaan dan kecintaan akan rumah yang selama ini ditempati.

Pelaksanaan munggah molo biasanya didahului dengan diadakan lek-lekan (begadang) sebagai suatu tanda kehidupan prihatin untuk tidak tidur, hal ini dimaksudkan agar rumah yang akan dibangun memberikan manfaat bagi penghuninya. Setelah itu akan diadakan selamatan, sebelum memakan dan membagikan makanan yang disediakan pada saat selamatan maka diadakan doa bersama. Berbagai macam makanan yang disajikan pada saat selamatan, yaitu nasi tumpeng yang dilengkapi lauk pauk, gudangan, tempe, lalap dan sambal: jajanan pasar; berbagai jenis bubur, buah-buahan, serta ingkung yang sepaket dengan nasi gurih. Puncak ritual munggah molo adalah pemancangan molo. Ula (2010: 6) menyebutkan bahwa bendera merah putih dibuat semacam kantong. Inilah yang dinamakan molo. Molo dipasang di 
tengah kayu salam yang memanjang, setundun pisang sepet, seonggok padi yang sudah menguning, empat buah kelapa, dan seikat tebu juga diikat dan digantungkan pada blandar (kayu penyangga atap). Beberapa keping uang receh dan uwat-uwat (obat) juga dimasukkan ke dalam molo.

Setelah prosesi munggah molo dilaksanakan maka para tukang akan merenovasi dan membangun rumah. Dulu proses munggah molo penuh dengan nuansa mistik yang tidak sesuai syariat Islam, tetapi saat ini proses munggah molo yang penuh mistik sudah mulai pudar karena adanya akulturasi antara budaya Jawa dengan Islam. Pada zaman dulu ubo rampe berfungsi sebagai sesaji, kini semua yang dipasang itu diperuntukkan bagi manusia yang tetap terpasang di atas hanyalah molo. Proses munggah molo ini dilaksanakan agar saat merenovasi atau membangun rumah tidak ada suatu kejadian buruk yang akan menjadi penghalang atau perintang yang menghambat proses renovasi dan pembangunan rumah serta diharapkan terjaganya keselamatan tukang dan pemilik rumah.

Dari segi keagamaan, munggah molo adalah perwujudan rasa syukur kepada Allah atas nikmat/ rezeki yang diterima, hal ini menyadarkan manusia untuk tidak sombong karena nikmat yang kita terima ini adalah karunia dari Allah. Manusia hanyalah makhluk ciptaan Allah. Munggah molo bila dilihat dari segi sosial merupakan suatu tradisi yang mengikat dan mendekatkan silahturahmi sesama warga karena mereka tolong menolong dan bergotong royong dalam melaksanakan selamatan.

Purwadi dalam Ula (2010: 11) mengatakan bahwa tradisi munggah molo merupakan warisan sosial yang hanya dapat dimiliki oleh warga masyarakat pendukungnya dengan jalan mempelajarinya. Pelaksanaan munggah molo merupakan alat efektif untuk menjaga sekaligus sosialisasi tradisi agar tidak punah.

Rasulan

Rasulan merupakan sebuah tradisi yang dilaksanakan setahun sekali, tetapi berlangsung selama beberapa hari. Biasanya rasulan dilakukan setelah masa panen. Hal ini tercermin dalam kutipan yang terdapat dalam novel Mars berikut ini.

Bergembiralah warga dusun dengan panen yang melimpah. Nama Tuhan diagung-agungkan, juga nama para makhluk halus sing mbaurekso dusun ini. Bukan dengan kata-kata, namun dengan menggelar upacara tradisi rasulan (Ang, 2011: 135).

Kutipan di atas menunjukkan bahwa warga Dusun Manggarsari merupakan masyarakat yang pandai bersyukur ketika 
menerima kelimpahan panen, rasa syukur itu mereka wujudkan dengan menggelar tradisi rasulan. Rasulan merupakan tradisi untuk mengungkapkan rasa syukur masyarakat akan keberkahan yang diterima dari Tuhan berupa panen yang melimpah. Bagi masyarakat Gunung Kidul, rasulan merupakan hari raya ketiga setelah Idul Fitri dan Idul Adha. Rasulan disebut juga sebagai bersih dusun. Makna tradisi rasulan ini sebagai tanda syukur atas karunia sang pencipta selain itu kebersamaan dan kekompakkan warga untuk menyiapkan rasulan merupakan nilai positif yang dapat memperkokoh rasa persaudaraan dan persatuan sesama warga.

Pada masa modern, rasulan telah dikemas menjadi salah satu event budaya khas Indonesia dan pengembangan wisata di kawasan Gunung Kidul. Pada rasulan diadakan kirab, arak-arakan mengelilingi desa dengan membawa tumpengan atau sesajian berupa hasil panen. Kegiatan ini diawali dengan kerja bakti membersihkan lingkungan sekitar dusun, puncak dari rasulan disemarakkan dengan berbagai kegiatan olahraga dan pertunjukkan seni budaya Gumbregan.

Selain munggah molo dan rasulan, ada juga tradisi masyarakat Gunung Kidul yang disebut gumbregan. Uniknya, gumbregan ini tidak ditujukan untuk manusia tetapi untuk hewan. Tradisi gumbregan ini terimplementasi dalam kutipan di bawah ini.

Hari itu di Manggarsari dan dusundusun lain, ada perayaan gumbregan, sebuah ritual selamatan yang diadakan untuk memanjakan hewan-hewan rojokoyo. Sapi, kambing, atau kerbau yang mereka pelihara. Ternak-ternak itu secara khusus diberi makanan berupa umbi-umbian direbus, ketan putih, dan ketupat (Ang, 2011: 114).

Tradisi gumbregan merupakan bukti sifat luhur masyarakat yang peduli dan sayang pada hewan ternaknya. Ucapan syukur dan kebijakan berbagi hasil bumi langsung kepada ternak adalah ucapan terima kasih dan keikhlasan dari pemilik kepada hewan ternaknya. Sajian dalam tradisi ini adalah makanan tradisional yang berasal dari hasil bumi seperti ketela, kimpul, nasi kupat, kolak pisang, jadah dan trembili. Ada juga among-among, yaitu nasi putih yang dibungkus daun pisang dan dibentuk lancip, ukurannya kecil dan diberi lauk pauk.

Latar belakang diadakannya gumbregan ini adalah karena masyarakat beranggapan bahwa hewan-hewan yang ada di dunia milik Nabi Sulaiman sehingga perlu dilakukan syukuran untuk menyelamati hewan-hewan tersebut. Pelaksanaan upacara biasanya dilakukan di rumah pemilik ternak, yang mengikuti tradisi ini adalah kaum laki- 
laki, si pemilik hewan atau anak laki-laki. Setelah berdoa dan memakan makanan sajian, ritual gumbregan dilanjutkan ke kandang hewan. Air bening yang telah didoakan dipercikan dan diusapkan kepada hewan sebagai ungkapan terima kasih.

Gumbregan ini sejatinya merupakan ungkapan rasa syukur dan terimakasih kepada Allah SWT akan kehadiran hewanhewan ternak. Gumbregan juga pengakuan dan penghargaan terhadap hewan ternak yang selama ini telah membantu dan meringankan manusia dalam mengerjakan pekerjaannya, bahkan meningkatkan taraf kehidupan manusia. Tradisi ini mengajarkan kita untuk menghargai jasa-jasa pihak lain, termasuk hewan. Banyaknya manfaat yang telah diberikan oleh hewan peliharaan membuat masyarakat Gunung Kidul sampai saat ini masih tetap melakukan acara syukuran atas rezeki dari hewan tersebut dengan melaksanakan tradisi gumbregan.

\section{Gaduhan}

Seseorang yang tidak mampu membeli hewan ternak berkesempatan untuk memiliki hewan ternak apabila ia mau merawat ternak milik orang lain. Hewan tersebut harus dirawat dan dijaga dengan baik agar hamil dan melahirkan. Sesuai kesepakatan pemilik dan perawat ternak maka perawat ternak dapat memiliki anak hewan tersebut. Hal ini dapat disimak dalam kutipan berikut.

Di Dusun Manggarsari dan sebagian daerah pedesaan lain di Gunung Kidul, menggaduh memang sudah menjadi tradisi yang tak bisa dipisahkan dari masyarakat, seseorang akan memelihara ternak (biasanya lembu dan kambing) milik orang lain dengan imbalan bagi hasil yang telah disepakati (Ang, 2011: 21).

Berdasarkan kutipan tersebut, dapat kita ketahui bahwa ada tradisi di masyarakat Gunung Kidul yang bernama tradisi gaduhan yaitu sebuah sistem pemeliharaan hewan ternak dimana pemilik hewan ternak, mempercayakan hewan ternaknya pada seseorang dengan imbalan bagi hasil. Sesorang akan memelihara ternak orang lain, yaitu memberi makan, membersihkan kotoran, membersihkan kandang, memandikan, mengawinkan hewan ternak tersebut dengan imbalan bagi hasil yang sudah disepakati. Jika ternak berupa indukan, bila beranak dua ekor maka dibagi rata, seekor untuk pemilik induk sedangkan seekornya lagi untuk pemelihara ternak tersebut. Jika yang digaduh itu beranak satu, anak hewan tersebut menjadi milik berdua. Bila dijual maka hasil penjualannya dibagi dua. Sementara jika yang digaduhkan itu jantan, maka perhitungan bagi hasil dilihat 
dari berapa nilai keuntungan pemeliharaan lantas dibagi dua. Bila dilihat dari segi ekonomi, tradisi ini merupakan tradisi mutualisme, artinya tradisi ini tidak hanya menguntungkan pihak pemilik ternak tetapi juga menguntungkan pihak perawat ternak/penggaduh. Keduanya akan mendapatkan penghasilan tambahan. Dari segi sosial, tradisi ini meningkatkan kepercayaan antar pemilik dan perawat ternak, juga hubungan silahturahmi antara kedua pihak.

\section{Kesenian}

Dalam masyarakat Jawa ada tembang yang memiliki filosofi tinggi yang disebut sebagai tembang macapat. Tembang macapat merupakan bentuk ungkapan yang dilagukan dalam sebuah 'pada' atau paragraf yang berisi mengenai kehidupan manusia dan nasihat-nasihat bagi manusia dalm menjalani kehidupan. Tembang macapat memiliki 11 jenis tembang, yaitu maskumambang, mijil, kinanti, sinom, asmaradana, gambuh, dandanggula, durma, pangkur, megatruh, dan pocung. Kesebelas tembang tersebut memiliki karakteristik yang berbeda-beda dengan watak masing-masing yang bila disatukan akan menggambarkan kisah perjalan hidup manusia mulai dari kandungan hingga meninggal dunia (www.pelajaran.click/2015/07/mengenal- tembang-mijil-secara-lengkap.html). Dalam novel Mars, tembang macapat ini terdapat dalam kutipan berikut ini.

\section{Poma kaki padha dipun eling}

Mring pitutur ingong

Sira uga satriya arane

Kudu antheng jatmika ing budi

Ruruh sarta wasis

Samubarangipun (Ang, 2011: 81)

Terjemahan tembang macapat

Tingkah laku harus diperhatikan

Di perkataan dan perbuatan

Bertindak yang adil

Harus anteng di tingkah laku

Berpengetahuan tinggi

Segala galanya

Kutipan lagu di atas disenandungkan oleh Tupon pada hari pertama Palupi bersekolah di sekolah dasar. Sesungguhnya Tupon yang lugu tidak terlalu mengetahui filosofi lagu tersebut, ia dapat menyenandungkan lagu tersebut karena ia sering mendengar majikannya menyanyikan lagu tersebut.

Di kalangan masyarakat Jawa, tembang ini disebut tembang mijil. Tembang mijil merupakan salah satu jenis dari tembang macapat.Tembang mijil tersebut berisikan petuah-petuah tentang akhlak yang harus dimilki manusia saat menjalani 
kehidupan di dunia ini. Manusia sebagai seorang khalifah di muka bumi ini harus memiliki akhlak mulia, bertingkah laku baik, santun dalam perbuatan, bertutur kata lembut, dan berkeinginan menuntut ilmu.

\section{Bangunan Adat}

Rumah memiliki fungsi sebagai tempat untuk berlindung dari hujan, panas dan marabahaya. Namun, rumah juga dapat mencerminkan identitas suku yang memilikinya. Masyarakat Jawa memiliki sebuah rumah adat berbentuk unik yang disebut joglo. Rumah adat Jawa ini terdapat dalam kutipan novel Mars berikut ini.

Berpuluh-puluh obor menerangi jalanan lalu memusat di sebuah rumah berbentuk joglo di samping balai dusun, rumahnya Kang Trimo (Ang, 2011: 69).

Bagi masyarakat Jawa, joglo merupakan rumah adat yang mencerminkan kepribadian dan keunikan suku Jawa. Keunikan joglo terletak pada atapnya, kerangka atap rumah joglo mempunyai bubungan yang tinggi. Hal ini terjadi karena 4 tiang bagian tengah yang digunakan untuk menyangga/menopang atap memiliki ukuran yang lebih tinggi dari tiang penyangga joglo yang lainnya. Rumah joglo juga memakai material yang berasal dari alam, berupa kayu keras untuk dinding, rangka atap, dan tiang sedangkan atapnya dapat terbuat dari ijuk, genting tanah liat, atau anyaman alang-alang. Kodiran (2010:334) menyatakan bahwa joglo adalah rumah bangsawan. Dulu tidak semua orang bisa memiliki bentuk rumah seperti joglo. Namun, zaman telah berubah, rumah joglo tidak hanya milik kaum bangsawan saja, kaum pribumi pun kini dapat memilki rumah joglo. Seiring berjalannya waktu, rumah joglo sudah semakin langka hal ini karena bentuk rumah tidak lagi mengikuti bentuk rumah tradisional tetapi ikut bentukbentuk rumah yang berasal dari luar negeri, yaitu rumah model minimalis ataupun mediterania.

\section{Agama dan Kepercayaan Tradisional}

Sebagian besar orang Jawa yang ada di Gunung Kidul menganut agama Islam, terdapat juga yang memeluk agama Katolik dan Hindu. Dalam kehidupan beragama, masyarakat Gunung Kidul yang terdapat di novel Mars memang telah menganut agama yang disarankan oleh pemerintah. Namun, agama bagi mereka tidak sepenuhnya dijalankan. Mereka masih percaya pada halhal yang bersifat takhyul dan klenik. Manifestasi tersebut tercermin dalam kutipan-kutipan berikut ini.

Hampir di setiap sendi kehidupan masyarakat dusun kering ini meringkus diri dengan pikiran-pikiran irasionaLTakhayul. 
Klenik. Mereka itu tentulah beragama Islam. KTP dan identitas lain mengatakan begitu. Tapi, mereka abangan. Sembahyang tidak dilakukan lima kali sehari, namun sekali saja dalam setahun. Shalat Idul Fitri saja (Ang, 2011: 66)

\section{Pak Antonius Wijaya-yang} rumahnya berdekatan dengan cakrukmisalnya. Dia seorang Katolik. Label agama di KTP-nya menyebutkan begitu. Namun pada kenyataannya , dia lebih sering membakar kemenyan setiap hari pasaran tertentu atau membaca kitab-kitab mujarobat seryta buku klenik lain daripada pergi ke gereja atau membaca kitab-kitab sucinya, Perjanjian Lama dan Perjanjian Baru (Ang, 20101: 68).

Kedua kutipan di atas menunjukkan bahwa masyarakat Gunung Kidul yang terdapat dalam novel Mars tidak ada yang tidak percaya akan keberadaan Tuhan. Tidak ada masyarakat yang atheis. Mereka percaya pada Tuhan sebagaimana mereka percaya kekuatan-kekuatan lain yang ada di antara mereka seperti Nyi Roro Kidul, Nyi Gadung Melati, dan mbaurekso. Masyarakat Dusun Manggarsari memang memiliki agama yang berbeda-beda tetapi kepercayaan dan keyakinan mereka terhadap dunia takhayul sama. Mereka masih sering meminta bantuan pada makhluk-makhluk gaib tersebut. Saking

percayanya mereka pada kekuatankekuatantak kasat mata tersebut, mereka juga tidak berani berlaku tidak pantas pada tempat yang mereka yakini dihuni oleh kekuatan tersebut. Bahkan, mereka akan berdoa dan memberikan sesembahan berupa makanan dan barang pada kekutan gaib tersebut. Hal ini tercermin dalam beberapa kutipan di bawah ini.

Hanya saja mereka juga masih mempercayai dan meminta bantuan-bantuan pada dunia takhayul pada Nyi Roro Kidul, Nyi Gadung Melati, dan dedemit-dedemit lain yang sekiranya mau bermurah hati memberi bantuan pada mereka. Mereka rajin dan tertib sekali melakukan ritual Selasa Kliwon dan Jum'at Kliwon di gua-gua. Juga memandikan keris-keris serta tombak pada awal sasi Suro (Ang, 2011: 67).

Di pojok selatan telaga, terdapat sebuah pohon beringin yang besar dan tua, mungkin sudah ratusan tahun usianya. Daunnya lebat dengan akar pohon yang bersulur-sulur. Masyarakat setempat mempercayai kalau pohon itu angker dan merupakan tempat tinggal sing mbaurekso dusun di sekitar telaga. Tak ada yang berani berbuat semrbono pada pohon itu. Takut kalau sing mbaurekso akan murka dan memberi hukuman pada penduduk (Ang, 2011: 14). 
Masyarakat Gunung Kidul juga melakukan tindakan gantung diri (Ang, 2011: percaya keberadaaan Pulung Gantung. 171)

Pulung gantung merupakan sebuah mitos

Kutipan di atas mengenai kematian yang sering dikaitkan dengan kasus bunuh Mbah Pangat dengan gantung diri di sebuah diri yang sering terjadi di Gunung Kidul. Pulung gantung digambarkan berbentuk sebuah bola api pijar yang berekor panjang seperti ular. Bola api ini berpijar dengan berbagai warna, bisa merah, kemerahmerahan ataupun merah kekuningan. Pulung gantung bergerak berpindah-pindah biasanya muncul sehabis magrib dan menjelang tengah malam. Tempat jatuhnya pulung gantung ini diyakini sebagai awal dari peristiwa bunuh diri yang akan terjadi. Apabila sebuah rumah dijatuhi pulung gantung dipercaya oleh masyarakat Gunung Kidul bahwa salah satu penghuni rumah tersebut akan mengakhiri hidupnya dengan gantung diri. Dalam novel Mars fenomena gantung diri karena pulung gantung ini direfleksikan dalam kutipan berikut.

Mbok Darmo mengaku melihat benda langit misterius-bercahaya kemerahmerahan dengan semburat hijau di bagian depannya-jatuh dengan cepat menuju rumah Mbah Pangat. Dengan segera, warga meyakini bahwa benda langit yang keramat itu adalah pulung gantung, sebuah benda langit yang mempunyai kekuatan gaib bisa memaksa orang yang kejatuhan itu untuk pohon. Mbah Pangat malam sebelum kematiannya masih terlihat menghadiri acara yang diadakan oleh warga. Bahkan Mbah Pangat masih berjudi dan bermain sinden, kematian Mbah Pangat yang tidak wajar tersebut kemudian dikaitkan dengan keberadaan pulung gantung yang dilihat oleh salah satu warga. Suwena dalam (www.news.detik.co,m/berita/3256628/miste ri-pulunggantung-fenomena-bunuh diri-33orang-per-tahun-di-gunung kidul) menyatakan bahwa maraknya kasus bunuh diri di Gunung Kidul terjadi karena pelaku bunuh diri terkena atau kejatuhan pulung gantung. Mitos pulung gantung ini melegimitasi tindakan bunuh diri masyarakat Gunung Kidul seharusnya pulung gantung ini dimaknai sebagai suatu gejala alam biasa. Namun, masyarakat memaknai sebagai pertanda atau isyarat kejadian bunuh diri dengan gantung diri.

Selain itu masyarakat Gubung Kidul yang terdapat pada novel Mars juga memiliki seorang rois dusun. Rois dusun ini adalah orang terpilih yang dipercaya memiliki doadoa mujarab dan keahlian memimpin ritual yang didapatkan secara turun temurun. Apabila ada masyarakat yang akan 
melakukan duwe gawe berupa pelaksanaan perkawinan, sunatan, atau membangun rumah, maka dicari hari baiknya berdasarkan hitung-hitungan klenik. Berkenaan hari baik ini terimplementasi dalam novel Mars ketika tokoh Ali diminta Kang Trimo untuk memimpin acara di rumahnya, waktu pelaksanaan acara itu ternyata dihitung berdasarkan klenik. Berikut ini kutipannya.

"Terus waktunya itu kapan, Kang?"

"Walah. Nyuwun pangapunten. Saya malah lupa," Kang Trimo tertawa sendiri, tapi hanya seb entar. "Mbenjing Senen Wage mawon, Mas, itu hari baik yang diberikan Ki Mangun Pekiki," lamjutnya. (Ang, 2011: 66)

Bagi masyarakat Jawa, hari baik sangat penting karena dipercaya membawa keberkahan, jadi bila melaksanakan sesuatu di luar hari baik maka dianggap mendatangkan musibah. Bahkan pada pasangan yang akan menikah akan dilihat dulu hari dan tanggal kelahiran kedua calon pengantin apakah cocok atau tidak. Bila berdasarkan hitung-hitungan tidak cocok maka keduanya akan batal menikah karena pernikahan mereka hanya akan membawa musibah. Namun, di masa modern ini perhitungan hari baik sudah tidak terlalu dijadikan patokan utama, terutama di daerah perkotaan, masyarakat beranggapan bahwa semua hari adalah hari baik yang patut disyukuri bukan diperdebatkan kebaikan atau keburukannya.

\section{KESIMPULAN}

Berdasarkan kajian yang telah dilakukan menunjukkan bahwa budaya Jawa yang terepresentasi dalam novel Mars begitu beragam. Keberagaman itu terlihat dari tradisi dan adat istiadat, kesenian, bangunan adat, serta agama dan kepercayaan tradisional. Dalam novel Mars diperlihatkan adanya tradisi munggah molo, rasulan serta gumbrengan yang merupakan wujud rasa syukur atas karunia dan berkah yang telah diterima dari Tuhan. Seiring berkembangnya zaman, tradisi tersebut tetap dipertahankan, meskipun dilakukan beberapa penyesuaian.

Ada juga tradisi gaduhan yang berlandaskan mutualisme antara pemilik dan perawat hewan tersebut. Dalam hal kepercayaan, masyarakat telah memiliki agama masing-masing, meskipun masih adanya kepercayaan akan hal-hal gaib dan mistis. Keberadaan mitos pulung gantung yang selama ini berkembang di masyarakat Gunung Kidul pun tercermin dalam novel Mars. Pulung gantung dianggap sebagai suatu penyebab banyaknya orang yang melakukan bunuh diri dengan menggantung dirinya. Mitos pulung gantung ini melegitimasi tindakan bunuh diri masyarakat Gunung Kidul. Namun, benar atau tidaknya 
mitos serta kejadian mistik tersebut patut dihargai sebagai suatu keunikan dalam suatu kebudayaan.

\section{DAFTAR PUSTAKA}

Ang, Aishworo. 2015. Mars. Jakarta: Qanita.

Aji, David Wisnu. 2014. Aspek kepribadian

Tokoh Utama Dalam Novel Mars Karya Aishworo Ang: Kajian Psikologi Sastra Dan Implementasinya Sebagai Bahan Ajar Di SMA. Skripsi, belum diterbitkan. Surakarta: Fakultas Keguruan dan Ilmu Pendidikan. Universitas Muhamadiyah Surakarta.

Endraswara,Suwardi. 2015. Metode Penelitian Antropologi Sastra. Cetakan kedua. Yogyakarta: Penerbit Ombak.

Kodiran. 2002. " Kebudayaan Jawa ”. Dalam Koentjaraningrat dkk (Ed).Manusia dan Kebudayaan di Indonesia.Jakarta: Djambatan.

Koentjaraningrat.1986. Pengantar Ilmu Antropologi. Jakarta: Aksara Baru.

Ratna, Nyoman Kutha. 2010. Sastra dan Cultural Studies Representasi Fiksi dan Fakta. Cetakan ketiga. Yogyakarta: Pustaka Pelajar.

Ratna, Nyoman Kutha. 2011. Antropologi sastra. Yogyakarta: Pustaka Pelajar.
Ratna, Nyoman Kutha. 2011. Teori, Metode, dan Teknik Penelitian Sastra: dari Strukturalisme hingga Poststrukralisme Perpektif Wacana Naratif. Yogyakarta: Pustaka Pelajar. Ula, Miftahul.2010."Tradisi Munggah Molo dalam Perspektif Antropologi Linguistik" Dalam Jurnal Penelitian, Volume 2, November, hlm 1-13.

www.news.detik.com/berita/3256628/misteri -pulung gantung-fenomena-bunuh diri-33-orang-per-tahun-di-gunung kidul. Diunduh pada 16 Juni 2017. www.gedangsari.com/inilah-sejarah-danseni-budaya-yang-masih-melekat-digunungkidul-yogyakarta.html.

Diunduh pada 15 Juni 2017.

www.pelajaran.click/2015/07/mengenaltembang-mijil-secara-lengkap.html. Diunduh pada 10 Juni 2017 